\title{
SEED SIZE AND PRESENCE OF THORNS IN Caryocar brasiliense ON SEEDLING EMERGENCE
}

\author{
Ricardo CARMONA ${ }^{1}$ (D), Daniel Franklin Nunes FERREIRA ${ }^{2}$ (D) , Thiago Estácio da COSTA ${ }^{3}$ (D), \\ Luís Carlos CARVALHO JÚNIOR ${ }^{3}$ (iD), Antônio Alves de OLIVEIRA JÚNIOR ${ }^{4}$ ic
}

\footnotetext{
${ }^{1}$ Faculty of Agriculture, University of Brasília, Brasília, Distrito Federal, Brazil.

2 Fazenda Água Limpa, University of Brasília, Brasília, Distrito Federal, Brazil.

${ }^{3}$ Graduate Program in Agronomy, University of Brasília, Brasília, Distrito Federal, Brazil.

${ }^{4}$ Postgraduate Program in Agronomy, Faculty of Agriculture, University of Brasília, Brasília, Distrito Federal, Brazil.
}

Corresponding author:

Ricardo Carmona

Email: rcarmona@unb.br

How to cite: CARMONA, R., et al. Seed size and presence of thorns in Caryocar brasiliense on seedling emergence. Bioscience Journal. 2022, 38, e38010. https://doi.org/10.14393/BJ-v38n0a2022-55572

\begin{abstract}
Commercial propagation of pequizeiro, which stands out among the main native fruits of the Cerrado region for its high economic potential, has been done by seeds, despite their erratic germination. The objective of this study was to evaluate the effect of seed size and presence of thorns on the endocarp on seedling emergence of pequizeiro in the field. Seeds were collected in a pequizeiro commercial area in Canarana-MT, Brazil. Due to availability, 2,353 thorny seeds (3 sizes) and 106 seeds without thorns (medium sized) were tested. Thorny seeds were classified as large - longer than $50 \mathrm{~mm}$; medium - between 40 and $50 \mathrm{~mm}$; small - less than $40 \mathrm{~mm}$. Seedling emergence started after 50 days in all seed categories, extending up to 100 days in the large seeds and to about 1 year after sowing in the small and medium sized ones. Small seeds showed a lower rate and speed of emergence compared to the others. Large seeds showed higher emergence speed compared to the medium ones. The presence of thorns did not affect seedling emergence. These results indicate the advantages of pequizeiro seed classification for sowing purposes.
\end{abstract}

Keywords: Emergence Speed. Germination. Seed Classification. Seed Dormancy.

\section{Introduction}

Pequizeiro is a fruit tree species largely distributed in the Brazilian tropical savanna biome (Cerrado), with a diversity of uses. Santos et al. (2013) highlighted its economic and cultural importance, since the pequi fruit pulp, in addition to cooking uses, stands out for its high oil content that can be used for therapeutic and biofuel purposes. It is rich in vitamin A and proteins, and can be used for treatment of bronchitis, asthma, and common colds, besides the antioxidant characteristics of the peel (Rocha et al. 2015). It can also be used in cosmetics industry, such as soap production. The pequi peel can be used as animal fodder, and the flour obtained from this part of the fruit can be included in quail diet (Oliveira et al. 2016). In addition, the peel extract and the mesocarp have a nematicide effect on the root knot nematode (Meloidogyne javanica) in tomato plants (Ribeiro et al. 2012).

The increasing demand for pequi fruits has led to the intensification of pequizeiro cultivation, which demands the production of commercial plants. According to Maranho et al. (2013) there is a growing need for the commercial production of native plants to supply the demand for the recovery of degraded areas and conservation areas; however, these authors emphasize the lack of information on the propagation of 
these species. In addition, commercialization of these fruits can yield an extra profit during the harvest season.

Pequizeiro plants are usually produced from seeds, despite their erratic germination rates, due in part to the occurrence of dormancy mechanisms (Rocha 2009) and other causes, such as high lipid contents, which are susceptible to peroxidation (rancification) processes, with negative effects on seed longevity. Lima et al. (2007) observed that lipids are the major component in both seeds (51.5\%) and mesocarp (33.4\%). Lipid peroxidation process (rancification) contributes to seed deterioration (Mendes 2015), thus reducing seed longevity. These factors contribute to the low success in obtaining seedlings from seeds, which limits the commercial expansion of this species.

Rocha (2009) described two mechanisms of dormancy in pequizeiro seeds - physical dormancy of the endocarp and embryonic dormancy, which can be alleviated with gibberellic acid (GA3). This growth regulator has been the main treatment in use to overcome pequizeiro seed dormancy (Carvalho et al. 1994). Even so, the responses of pequizeiro seeds to GA3 are variable. Leão et al. (2012) observed average germination percentages ranging from $5 \%$ to $57 \%$ with gibberellic acid (GA3) and from $3 \%$ to $56 \%$ without it. The average period required for pequizeiro seedling emergence was 52 days in the presence and 59 days in the absence of GA3, confirming its low effect. According to these authors, seedling emergence starts at 30 days after sowing, extending up to 128 days, probably due to seed dormancy mechanisms.

Germination depends on several factors, such as seed viability and vigor (physiological quality) besides environmental factors. Seed size can also be correlated with physiological quality, since larger seeds store more reserves, which generally results in more vigorous seedlings (Carvalho and Nakagawa 2012; Geritz and Toivonen 2018). Silva et al. (2010) observed that smaller seeds of jackfruit (Artocarpus heterophyllus Lam.) resulted in lower seedling emergence rates compared to the larger ones. In contrast, Nietsche et al. (2004) did not find significant effects of seed size on emergence rates of cagaita (Eugenia dysenterica) seedlings; however, larger seeds germinated faster than the small ones.

There is evidence about the occurrence of germination inhibitors in the endocarp and thorns of pequizeiro. Melo and Gonçalves (2001) observed a reduction in the speed of seed germination on lettuce (Lactiva sativa L.) in the presence of aqueous thorns and endocarp extract of pequi. The removal of these structures, however, can cause mechanical damage to the seeds, due to the rigidity of the endocarp combined with the fragility of the seed.

The objective of the present study is to evaluate the effects of pequizeiro seed size and the presence of thorns on seedling emergence in the field.

\section{Material and Methods}

Pequizeiro fruits were collected on November 10, 2018, from planted matrices of about 20 years old, in the region of Canarana/MT. Ripe fruits were manually collected on the ground, separately from matrices containing or not thorns on the endocarp. In order to avoid possible effects of the genotype on seedling emergence, fruits of different matrices were mixed for homogenization purposes and transported in polypropylene bags to Fazenda Água Limpa (Universidade de Brasília), in Brasília/DF.

Two days after collection, the fruits were cut and the exocarp (peel) discarded. In order to remove the mesocarp, putamens (endocarp containing seed and mesocarp, hereafter referred to as seeds) were naturally fermented openly in a warehouse for four days, at environmental temperatures (Melo and Gonçalves 2001). The seeds were then shaken in a concrete mixer, along with sand, gravel, and water, for 35 minutes, to separate the fermented mesocarp from the endocarp. Seeds were then washed over a sieve, until the complete removal of sand, gravel and the remainings of mesocarp and dried out for 3 days in a warehouse (Melo and Gonçalves 2001).

Damaged seeds (rotten, perforated, dark) were discarded, and the rest were treated with 500 grams of Orthocide 500 (Captan) per $40 \mathrm{~kg}$ of seeds, to prevent fungi incidence. Seed average mass, regardless the presence of thorns or classification, evaluated in eight replicates of 100 seeds, was 18.5 grams. Thorny seeds were classified in three sizes: large - more than $50 \mathrm{~mm}$ length (56 seeds), medium - between 40- and 50 $\mathrm{mm}$ length (1,147 seeds) and small - less than $40 \mathrm{~mm}$ (1,150 seeds), using an amount of 2,353 seeds. One hundred and six seeds without thorns (all medium sized, due to the absence of other sizes in this lot) were also tested. 
The classified seeds were sown on November 20, 2018, in a 1-meter width seedbed containing $50 \%$ sand and $50 \%$ subsoil (red latosoil collected at $20-40 \mathrm{~cm}$ layer), in $7 \mathrm{~cm}$ depth furrows spaced $20 \mathrm{~cm}$ apart. Seeds were arranged in an upright position with the epicotyl facing upwards and the radicle downwards, in a density of 20 medium or large seeds and 25 small seeds per linear meter. The seeds were covered with a 2 to $3 \mathrm{~cm}$ sand/subsoil (1:1) layer mixture and the seedbed with dry straw, to reduce direct sunlight, evaporation and weed development. The seedbed was irrigated throughout the experimental period, as needed, by sprinklers. Manual weed control was undertaken every 15 days.

Seedling emergence was evaluated on a weekly basis, from January 07,2019 , when emergence begun and transplanted to $20 \times 35 \mathrm{~cm}$ perforated plastic bags. The percentage of accumulated seedling emergence, in relation to the total sown (observed), and the accumulated seedling emergence in relation to the total of seedlings emerged (relative) were evaluated, using polynomial regression with each respective equation, for all seed categories. Thirty days after the end of the seedling emergence period, 20 large seeds, 100 medium seeds and 100 small seeds were exhumed from the soil in order to observe if their tissues were still fresh or rotten.

\section{Results and Discussion}

Pequizeiro seeds showed slow initial germination, as seedling emergence started about 50 days after sowing in field conditions of the present experiment (Figure 1). This period is longer than the 35 days observed by Silva and Leonel (2017) and the 30 days observed by Leão et al. (2012) for the beginning of germination of pequizeiro seeds, probably due to different environmental conditions or seed dormancy. At least two dormancy mechanisms have been attributed to pequizeiro seeds - mechanical restriction of the endocarp and physiological embryonic dormancy (Rocha 2009).

At 100 days after sowing, the relative emergence reached $100 \%$ in the large seeds (over $50 \mathrm{~mm}$ length), while at this moment the relative emergence was around $60 \%$ in the medium and small seeds (up to $50 \mathrm{~mm}$ length) (Figure 1). In these seeds, emergence extended until about 1 year after sowing (Figure 1). Similar results were obtained by Leão et al. (2012), who observed the emergence of pequizeiro seedlings up to 128 days after seed sowing.

In addition to the long germination period, germination process was also dependent on seed size (Figure 1). The results of the present study show that the size of pequizeiro seeds is inversely proportional to the time necessary for seedling emergence. Wagner Júnior et al. (2011) also observed that larger seeds showed higher germination and seedling emergence rates compared to the smaller ones in Jabuticaba Sabará (Myrciaria jaboticaba (Vell.) O. Berg) and in Jabuticaba de Cabinho (M. peruviana var. trunciflora) seeds. In contrast, Nietsche et al. (2004) did not observe significant effect of seed size on seedling emergence rate of cagaita (Eugenia dysenterica) - a native Cerrado fruit - but also concluded that bigger seeds entail faster seedling emergence. For Pereira et al. (2011), the influence of seed mass on germination and vigor can be relative, varying between species and regions.

Seed size also affected the final seedling emergence percentage, once the accumulated emergence in small seeds was about $20 \%$ after one year (Figure 1), whereas in medium and large ones ( $>40 \mathrm{~mm}$ length) the accumulated emergence exceeded $30 \%$. These emergency rates agree with the results obtained by Leão et al. (2012), who observed germination rates varying from $3 \%$ to $56 \%$ in pequizeiro seeds.

The presence of thorns in the endocarp did not affect seedling emergence. The observed and relative accumulated emergence of medium seeds (40 to $50 \mathrm{~mm}$ length) with or without thorns were similar (Figure 1). In contrast, Melo and Gonçalves (2001) observed a decrease in germination speed of lettuce seeds (Lactuca sativa L.) in the presence of aqueous thorn and endocarp extract of the pequi fruits, which denotes the presence of germination inhibitors in these structures.

All the seeds retrieved from the soil thirty days after the end of the seedling emergence period (20 large, 100 medium and 100 small size) were rotten and smelly, which indicates that non-germinated seeds were non-viable at the end of the experiment.

These results demonstrate the importance of seed classification by size on pequizeiro. In order to improve rate and speed of emergence, small seeds (less than $40 \mathrm{~mm}$ length, in the studied accesses) should be discarded. Medium and large seeds (more than $40 \mathrm{~mm}$ ) have similar final emergence, but large seeds (more than $50 \mathrm{~mm}$ length) germinate faster (up to 100 days after sowing). Apparently, in this species there 
is a direct correlation between the amount of reserve in the seeds and the rate and speed of emergence and, consequently, in seed vigor. Thus, large seeds are the most suitable for sowing purposes.

A: Small seeds
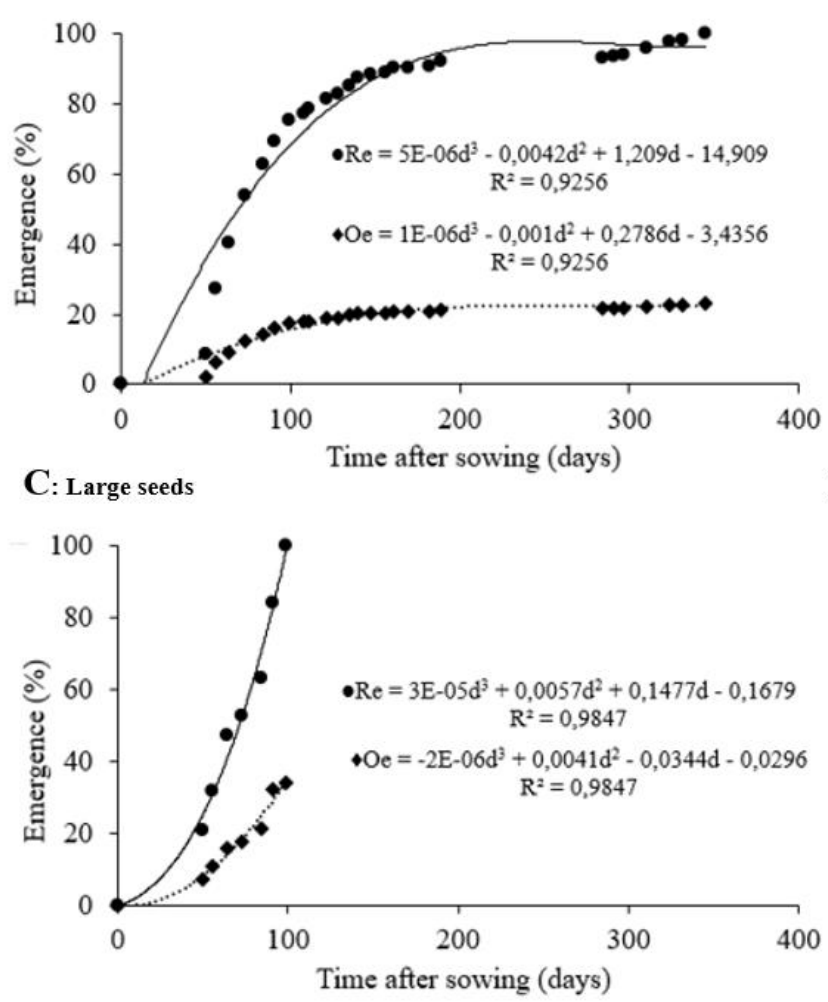

B: Medium seeds

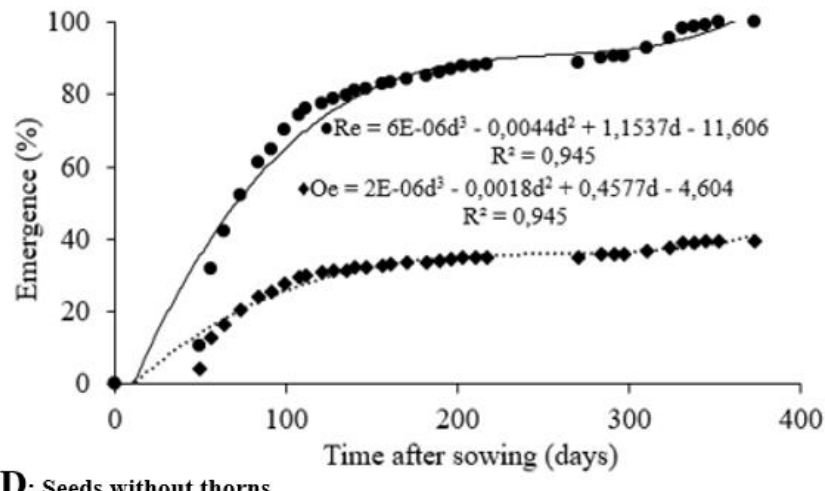

D: Seeds without thorns

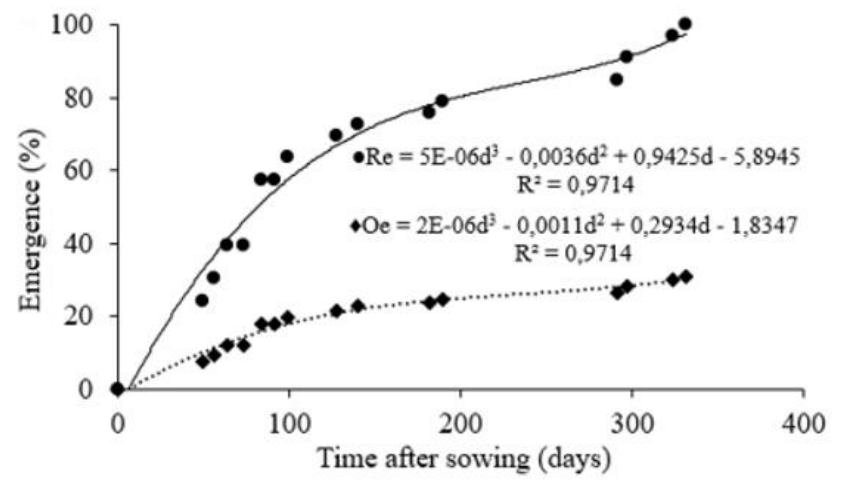

Figure 1. Observed $(\bullet, \mathrm{Oe})$ and relative $(\bullet, \mathrm{Re})$ emergence of pequizeiro seedlings over time after sowing for: A - small seeds (smaller than $40 \mathrm{~mm}$ ); B - medium seeds (40 to $50 \mathrm{~mm}$ ); C - large seeds (above 50 $\mathrm{mm}$ ); and D - seeds without thorns (medium size).

\section{Conclusions}

Seedling emergence is a slow process in pequizeiro, taking up to a year for medium and small seeds. Seed (putamen) size affects rate and speed of seedling emergence. Small seeds (smaller than $40 \mathrm{~mm}$ length, in the studied accesses) should be discarded since they generate smaller rate and speed of seedling emergence. Medium and large seeds (longer than $40 \mathrm{~mm}$ ) imply higher seedling emergence rates, and large seeds (from $50 \mathrm{~mm}$ length) generate also higher emergence speed.

The presence of thorns in the pequizeiro seeds does not affect rate and speed of seedling emergence.

Authors' Contributions: CARMONA, R.: conception and design, acquisition of data, analysis and interpretation of data, drafting the article; FERREIRA, D.F.N.: acquisition of data, drafting the article; COSTA, T.E.: acquisition of data, drafting the article; CARVALHO JÚNIOR, L.C.: acquisition of data, drafting the article; OLIVEIRA JÚNIOR, A.A.: analysis and interpretation of data, drafting the article. All authors have read and approved the final version of the manuscript.

Conflicts of Interest: The authors declare no conflicts of interest.

Ethics Approval: Not applicable.

Acknowledgments: The authors are grateful to Mr. Edemo Correia (Sítio Água Limpa, Canarana/MT) for providing the seeds for this study. The authors are also grateful to the University of Brasília (UnB) for the infrastructure support.

\section{References}

CARVALHO, C.G.S., et al. Efeito de diferentes tratamentos na germinação do pequi (Caryocar brasiliense Camb.). Acta Botânica Brasilica. 1994, 8(1), 109-120. https://doi.org/10.1590/S0102-33061994000100011

CARVALHO, N.M. and NAKAGAWA, J. Sementes: ciência tecnologia e produção. 5th ed. Jaboticabal: Funep, 2012.

GERITZ, S., GYLLENBERG, M. and TOIVONEN, J. Adaptive correlations between seed size and germination time. Jornal of mathematical biology. 2018, 77, 1943-1968. https://doi.org/10.1007/s00285-018-1232-z 
LEÃO, E.F., PEIXOTO, N. and MORAIS JÚNIOR, O.P. Emergência de plântulas de pequizeiro em função da planta matriz e uso de ácido giberélico. Pesquisa Agropecuária Tropical. 2012, 42(4), 416-423. https://doi.org/10.1590/S1983-40632012000400009

LIMA, A., et al. Composição química e compostos bioativos presentes na polpa e na amêndoa do pequi (Caryocar brasiliense, Camb.). Revista Brasileira de Fruticultura. 2007, 29(3), 155-159. http://dx.doi.org/10.1590/\$0100-29452007000300052

MARANHO, A., PAIVA, A.B. and PRADO DE PAULA, S.R. Initial growth of native species with timber potential in Amazon, Brazil. Revista Árvore. 2013, 37(5), 913-921. https://doi.org/10.1590/S0100-67622013000500014

MELO, J.T. and GONÇALVES, A. N. Inibidores de germinação em frutos e sementes de pequi. 1st ed. Brasília: Embrapa Cerrados, 2001. Available from: http://ainfo.cnptia.embrapa.br/digital/bitstream/CPAC-2010/23731/1/bolpd-23.pdf

MENDES, D.S.T. Germinação e armazenabilidade de sementes de pequizeiro. Montes Claros: Universidade Federal de Minas Gerais, 2015. Available from: http://hdl.handle.net/1843/NCAP-9Y7G4L

NIETSCHE, S., et al. Tamanho da semente e substratos na germinação e crescimento inicial de mudas de cagaiteira. Ciência e Agrotecnologia. 2004, 28(6), 1321-1325.

OLIVEIRA, M.C., et al. Pequi peel flour in diets for Japanese quail. Acta Scientiarum. Animal Sciences. 2016, 38(1), 101-106.

https://doi.org/10.4025/actascianimsci.v38i1.28381

PEREIRA, S.R., et al. Tamanho de frutos e de sementes e sua influência na germinação de jatobá-do-cerrado (Hymenaea stigonocarpa var.stigonocarpa Mart. ex Hayne, Leguminosae - Caesalpinoideae). Revista Brasileira de Sementes. 2011, 33(1), 141-148.

https://doi.org/10.1590/S0101-31222011000100016

RIBEIRO, H.B., et al. Resíduos de frutos de pequi no controle do nematoide das galhas em tomateiro. Horticultura Brasileira. 2012, 30(3), 453458. http://dx.doi.org/10.1590/S0102-05362012000300016

ROCHA, J.P. Fatores genéticos e ambientais na emergência de plântulas de pequizeiro (Caryocar brasiliense camb.). Diamantina: Faculdade de Ciências Agrárias, Universidade Federal dos Vales do Jequitinhonha e Mucuri, 2009. Tese de doutorado.

ROCHA, L.B., et al. Gallic acid as the major antioxidant in pequi (Caryocar brasiliense Camb.) fruit peel. Revista Brasileira de Plantas Medicinais. 2015, 17(4), 592-598. https://doi.org/10.1590/1983-084X/14_062

SANTOS, F.S., et al. A cultura do Pequi (Caryocar brasiliense Camb.). Acta Iguazu. 2013, 2(3), 46-57.

SILVA, K.S., et al. Influência do tamanho da semente na germinação e vigor de mudas de jaqueira (Artocarpus heterophyllus Lam.). Revista Verde. 2010, 5(4), $217-221$.

SILVA, E.C. and LEONEL, L.V. Avaliação da germinação de sementes de pequizeiro (Caryocar brasiliense Camb) submetidas a diferentes concentrações de ácido giberélico. Cultura Agronômica. 2017, 26(2), 217-223.

WAGNER JÚNIOR, A., et al. Germinação e desenvolvimento inicial de duas espécies de jabuticabeira em função do tamanho de sementes. Acta Scientiarum Agronomy. 2011, 33(1), 105-109. https://doi.org/10.4025/actasciagron.v33i1.4881

Received: 7 May 2020 | Accepted: 16 July 2021 | Published: 16 February 2022

This is an Open Access article distributed under the terms of the Creative Commons Attribution License, which permits unrestricted use, distribution, and reproduction in any medium, provided the original work is properly cited. 